\title{
Newspaper Coverage of Women in Politics: A Content Analysis Of Daily Trust and Punch Newspapers
}

\author{
https://doi.org/10.21272/sec.3(2).70-77.2019
}

\author{
Abubakar Bappayo \\ MSc, Senior Lecturer, Abubakar Tatari Ali Polytechnic Bauchi, Bauchi State, Nigeria \\ Yushau Haruna Kirfi
}

Bsc, Lecturer, Department of Mass Communication Abubakar Tatari Ali Polytechnic Bauchi, Bauchi State, Nigeria

\begin{abstract}
This paper summarizes the arguments and counterarguments within the scientific discussion on the issue to ascertain how well Nigerian newspapers cover women in politics. It's also identified the pivotal role of the mass media in the promotion of women in Nigerian politics. The main purpose of the research is to find out the women who participate in politics by planning and maintaining message take campaigns for general awareness about the potential leadership qualities of women and also the empowerment and autonomy of women. Methodological tools of the research methods were simple random sampling technique was adopted and data collection for the study was code sheet which was contain the parameters, for the study period of eight months, 422 stories were gathered out of which only 56 were in politics. Therefore, the presentation and analysis of the data showed that the Nigerian newspapers did not give women in politics the desires coverage it required as compared to their male counterparts. Also, the study reveals that mass media is pivotal to social change and have the potential to increase the number of women aspirants to political offices. The result of the research can be useful as an additional literature on newspaper coverage of political issues as well as be of immense value to the media as it enlightens and educate the media professionals on how to play their fundamental role in the quest to eradicate gender discrimination of all types. The researchers conclude that Nigerian women still have a long way to go in attaining the pinnacle of political decision making and it is apparent that women's struggle to get relevant in political leadership continued of be hindered by certain factors, and recommends among others, that the media should give prominent coverage to women who have performed exceptionally well in politics and also create a platform to enlighten them about their political rights as well as the creation of political institutions, development partners and other donor agencies of facilitate women participation in politics and this can be successfully done through the mass media. It is therefore, pertinent for media professionals to play their fundamental role in the quest to eradicate gender discrimination of all types.
\end{abstract}

Keywords: newspaper coverage, women, politics, daily trust and punch newspapers. JEL Classification: Y.

Cite as: Bappayo, A., Kirfi, Y.H. (2019). Newspaper Coverage of Women in Politics: A Content Analysis Of Daily Trust and Punch Newspapers. SocioEconomic Challenges, 3(2), 70-77.

https://doi.org/10.21272/sec.3(2).70-77.2019.

(C) The Authors, 2019. This article is published with open access at Sumy State University.

\section{Introduction}

In today's globalized world, one universal Yardstick for measuring national development especially in developing countries of Sub-Saharan Africa and Asia, is the assessment of the Millennium Development Goals (MDGs) to be achieved on or before 2015 (Ogbiti and Onsu, 2012). Experiences have revealed that women folk do not have equal status with men folk in elective posts in political circles which negates goal three of MDGs (now SDGs) which is gender equality.

Active participation of women in politics cannot be achieved without genuine communication system. Communication server as a vehicle through which different segments of people relate with each other. Communication system are an approaches to issues, in respective of their personality. Effective communication of political dispensation can only be achieved through mass media. The mass media have the potential to assist in 
the constant promotion of women participation in politics by planning and mouthing messages such as sustainable enlightenment campaigns for general awareness about the potential leadership qualities of women and their role in sustainable development in Nigeria. Enebek, (2008).

According to Hamid, A.M. et..al (2014), Democracy cannot folly take its roots in societies or countries where there are not no free and vibrant mass media. Free and vibrant media actually free people's mind because they allow them the liberty to make contributions on how they are being governed. Among other things, the media perform the functions of educating, informing and entertaining in addition to being a platform for mobilization, persuasion etc. vibrant media are interview with democratic governance because repressive regimes don't tolerate being put on the media scale of public discourse to examine their stewardship.

Since the return to democratic rule in 1999, Nigerian women have tried to gained access to political decision making position by contesting for elective position at various levels. Their efforts however have not translated to appreciative gain as subsequent elections since 1999 revealed. Not only has there been marginal gain over the years which in itself is not very encouraging, but a decline in the number of elected female politicians in the 2015 general election shows a manifestation of female political disempowerment and this is more worrisome.

Women struggles date back to the $19^{\mathrm{TH}}$ century when women like Amina of Zaria, Madam Tinubu of Lagos, Olufunmilayo Ranson Kuti of Abeokuta, Margaret Ekpo and Hajiya Gabon Swabia among others fought to give women the pride of place in Nigeria's history. Even after the struggle for independence was over and Nigeria become an independent sovereign nation, women continued to contribute their quota in the postindependence match towards development and progress in the area of politics, the above named among others contributed immensely to the mobilization and sensitization of women with a view to ensuring that women are involved in the politics of the country. Andrew, H.C. (2015).

Prior to the $21^{\text {ST }}$ century, most Nigerian women tended to be indifferent towards politics. This could be attributed to some issues or factors ranging from the nature of the Nigerian society which is patriarchal with the prevalent nation that politics is not for women and also the high illiteracy rate among women. In the $21 \mathrm{TH}$ century, there seems to be a slight change. Many Nigerian women have not only become actively involved in politics, some of them have also recorded great successes in political circles (Nwammu, 2012).

More so, the establishment of women bodies and vanguards such as the Liberal National Council of Women Societies in Nigeria (LNCWSN) Women in Nigeria (WIN) and the recommendation of women in politics of today. The Universal Declaration of Human Rights of 1948 is significant in the respect. It states that everyone has the right to taken part in the government of his/her country. Also, United Nations Declaration On Democracy (UNDP) earmarked 30 percent as the minimum percentage of women representation in all sphere of decision making. The empowerment and autonomy of women and the improvement of transparent and accountable government, administration and sustainable in all areas of life (World Bank, 2005).

In spite of the universal Declaration of Human Rights and the United Nation recommendations and government policy on women, the response of women in active political participation in Nigeria remains tepid and non-aggressive, especially in elective (political) positions at various tiers of governance.

\section{Politics and mass media}

Politics according to Okechukwu (1997) can be defined as the art or science of government or governing especially the governing of a political entity, such as a nation and the administration and control of its internal affair. He also views it as "the complex or aggregate of relationships of people in society especially those relationship involving authority."

It is therefore, important that in a truly deliberative and participatory democracy the main channels of political communication be open and inclusive enough to accommodate the full range of voices available in the polity. (Oso, 2012).

Mass media are windows through which we can view the landscape of politics within one nation. The mass media have exerted and are still exerting great influence on a wide range of political and social issues as powerful communication tools. Media can be used as political instrument for building a nation and promoting the legitimacy of a regime by shaping the nation's political culture and influencing its public opinion. The media force attention to certain issues, they build up images of political figures, they are constantly presenting objects suggesting what individual should think about and having about. 


\section{Statement of problem}

Women attempting to enter in to politics in Nigeria face numerous obstacles. Those who have aspired to office must often deal with a lack of funds to run an effective campaign a discriminative use of party zoning low education and show of cultural and religious barriers. The marginalization of women in politics is certainly not new to Nigeria, having dated back to colonial times. In fact, women did not gain the right to vote until 1976 (Effah, 2002).

Though there was improvement in the participation of women in the 2015 general elections but in Nigeria politics, sexism has become a major predicament. Women have been politically considered as an endangered species and their low participation in Nigerian government and politics is often associated with cultural, religious and economic constraints and male chauvinism (Umechukwu, 2004).

The mass media provides perspectives, shape images of candidates and parties help highlight issues around which a campaign would develop. It also defines the unique atmosphere and areas of sensitivity with any particular campaign (Lang and Land 1999).

This research therefore seeks to find out how well newspapers cover women's participation in politics in Nigeria.

\section{Purpose of the study}

To find out the women who participate in politics by planning and maintaining message take campaigns for general awareness about the potential leadership qualities of women and also the empowerment and autonomy of women and the improvement of women's social, economic and political status.

\section{Objective of the study}

To ascertain the prominence given to the reports on women's participation in the 2015 general elections.

\section{Research questions}

What was the prominence given to the reports on women's participation in the 2015 general elections?

\section{Theoretical scope}

The development media theory according to Mcquail, (1987) as cited in florin, (2002) was propounded by Denis Mcquail in the $18^{\mathrm{TH}}$ century. This theory seeks to explain the role of the media in development process. Rather than lay too much emphasis on issues like crimes, disaster and so on advocates of this theory argue that the primary responsibility of the media in a developing country is to promote the much - needed development and transformation in the society.

In the light of the principle of the Development Media theory, it is important that the Nigerian media are in the forefront in the promotion of gender equality and empowerment by planning and mounting sustainable enlightenment campaigns for general awareness about the potential leadership qualities of women and their role in sustainable development in Nigeria. The media have a crucial and increasing role to play in shaping the image of women politicians instead of acting as mere mirror of the social and cultural traditional patterns, the media should become an agent of change through their approach to women or rather to gender at large.

\section{Literature review}

Elections can be a key either in both conflict resolution and conflict escalation. Therefore, free and fair elections are essential for democracy consolidation and conflict prevention. The professionalism of media election coverage regardless of gender, United Nations Educational, Scientific and Cultural Organization (UNESCO) supports advocacy to encourage full, fair and efficient disclosure of information to journalists covering the elections, training to enhance professional election reporting, training on the safety of journalists and their right to work without threat and the production and distribution of election guidelines reflecting principles of professional reporting during elections, journalists rights law with emphasis on freedom of expression.

It is a truism that the media play an indispensable role in the proper functioning of a democracy. Discussion of the media's functions usually focuses on their "watchdog" role: by unfettered scrutiny and discussion of the success and failures of governments and media can inform the public of how effectively its representatives have performed and help to hold them to account. 


\section{Women and political participation in Nigeria}

Political participation as one of the key elements of democracy provides the justification for inclusion of marginalized groups such as women and youth in electoral competition. Participation of women in politics will be meaningful only if the process is just fair permissive and level playing ground is guaranteed for possible ascension of women politically.

Politics has strategic importance for women because the ultimate success of women's movement will rest heavily on effective use of the political process to get to political process. Women's ability to effectively use the political process to get to political positions may increase their representation in elective positions and effect public policies. However, it is very clear from Nigeria's experience that the political process is male dominated and men influence the process more than women (Lynn, 1978).

Momodu (2003) submits that the issues of women's political participation and representation in politics and governance should be seen from four perspectives: Access, Participation, Representation and Transformation. Access to political institutions participations (which includes control of power within such institutions) quantitative and qualitative representation and the end result will be social and political transformation in the policy. Women's political empowerment can be enhanced when these four conditions are fulfilled.

The view that women in politics matter is sustained by three reasons: First, politics is an important arena for decision making. Individuals who hold official position in government get to decide how to allocate scare resource, such as tax revenues. Politicians make political decisions that may help some people at the expense of others. Decisions by politicians often affect people's individual choice by encouraging some behaviors and outlawing others. Second, political power is a valuable good. Politicians hold power over social institutions, such as the family. Third, holding a political position is to hold a position of authority. Women in positions of authority and power can influence decision on issues that bother on women and impact positively on the lives of female gender (Paxton, 2007).

Dovi (2006) provides at least seven distinct arguments why representative is necessary. The role model argument, the justice argument, the trust argument, the increase participation argument, the legitimacy argument, transformative argument and the over looked interest's argument. Each of these arguments, according to her points to a different function that female representatives can have in democracies and quoted in extensor.

During the 1990 elections into Local government councils that heralded the third republic, very few women emerged as Councilors and women, Chief (Mrs) Titilayo Ajanaku, emerge as chairperson of Abeokuta Local government council in Ogun State. During the gubernatorial elections, no female governor emerged in any states. Only two female deputy governors emerged, namely: Alhaji Sinatu Ojikutu of Lagos State and Mrs. Cecilia Ekpeyong of Cross River State. In the Senetorial election held in 1992, Mrs Kofo Buchnor Akerele was the only women won a seat in the senate. Very few women won election into the House of Representatives. One of these few was Chief (Mrs) Florence Ita Giwa who won in the Calabar constituency under the banner of the National Republic Convention (NRC). President Ibrahim Babangida in January 1993 appointed two women as members of the transitional council namely: Mrs Emily Aig-Imuokuesd and Mrs Laraba Dagash.

In the Interim Natinal Government of Chief Ernest Shonekan, two female Ministers were appointed into the cabinet. General Abacha had a number of female Ministers at various times in his cabinet, including Chief (Mrs) Onikepo Akande and Ambassador Judith Attah. During the military regime of General Abdulsalami Abubakar (June 9, 1998 to May 29, 1999), there were two women in the federal executive council: Chief Mrs Onikepo Akande (Minister of Commerce and Dr Laraba Gambo Abdullahi (Minister of Women Affairs), (as cited by Adedotun, 2012).

\section{Exemplary roles of some female appointees in politics}

Mrs. Oby Ezekwesili is credited with established due process as a standard in Nigerian Government and civil service. She also performed excellently as the Minister of solid minerals The Minister of Finance, Dr Okonjo Iweala, ably steered the direction of president Obasanjo's economic reform agenda. She led the negotiation that resulted in the cancellation of 18 million dollars of Nigeria's foreign debt. The role she played in the economic sector during the regime of Obasanjo necessitated her re-appointment as Minister of Finance in the Jonathan Administration (Effah, 2002). The level of education they acquired coupled with the role they played in their respective offices prior to their ministerial appointments as well as the support given to them by the president of the nation led to the exemplary role women displayed. These women and several others have 
demonstrated that women are capable of delivering quality and positive leadership which enhance national development and sustainable economic growth.

\section{Mass media enhancement of women participation in politics}

The mass media as technological device of mass communication is established to inform, educate and mobilize. The four function are vital in the democratization process of any nation whether in homogenous or plural societies. Mass media provide entertainment to its audience especially women by sneaking in political message to its listeners while it is entertaining them.

The mass media in democratic setting are conscience of the nation; they initiate, sustain and reformed democracy. (Daramola, 2012) citing Lass well (1948) identified three functions performed by mass media namely: surveillance of the world to report ongoing events interpretation of the meaning of events and socialization of individuals into their cultural settings. Another attribute of the media of the deliberate manipulate of the political process.

In the same vein, Wogu (2003) noted that the media play a key role in the building of political fabric of a democracy. Political leaders employ them as instruments of political education and mobilization while the masses use them as channel for feedback. A wise decision on the part of the people depend on level of objective and correct information disseminated. Thus, the media structure the world to the audience. They bring the existence of phenomena to the knowledge of the people and likewise to the government. Mass media also liberate the masses through political education. Mass enlightenment of the people Practioners will enable the masses to appreciate their political rights and obligations. Akinfeleye (1995) states that, "Communication network required for making linkages possible is therefore to mind a powerful too for the sustenance of democracy." It is an accelerator of democracy a catalyst for effective democracy, tranquillizer for democracy and a lot of damage to democracy.

\section{Research methodology}

The research design for the study was content analysis. The study analyzed stories of political newspapers and the coverage of women in politics to answer the research questions raised in the study.

\section{Population of the study}

The universe in the study refers to all the National Daily Newspaper published and circulated in Nigeria. According to the Corporate Affairs Commission of Nigeria (CAC) as at 2011 the total numbers of national newspaper to be 35. Therefore, the universe in this study refers to two Nigerian newspapers. Which include: The trust Newspaper and The Punch Newspaper.

\section{Sample size}

The sample size for the study was 192 issues of the newspaper under study.

\section{Sample techinique}

Simple random sampling technique was adopted.

\section{Instrument of data collection}

The instrument of data collection for the study was code sheet which was contain the parameters of analysis.

\section{Unit of analysis}

Unit of analysis here referred to the actual thing counted when coding which tested based on prominence, frequency of reports, quality of reports and source of reports.

\section{Data presentation and analysis}

Table 1. Frequency distribution table on the coverage of women by daily trust and the punch newspapers.

\begin{tabular}{|c|c|c|}
\hline Newspapers & Frequency & Percentage \% \\
\hline Daily trust & 223 & $53 \%$ \\
\hline Punch & 199 & $47 \%$ \\
\hline Total & 422 & $100 \%$ \\
\hline
\end{tabular}

Source: fieldwork, 2018. 
From the table 1 above, it shows that, 223 stories representing 53\% of the total number of published stories on women in politics were published by Daily trust newspaper, while the punch Newspaper recorded a total of 199 stories, representing $47 \%$ of the stories were reported on 2015 general elections by the newspaper with Daily trust leading with a total of 223 stories.

Table 2. Coverage of women in the 2015 general elections according to the content categories.

\begin{tabular}{|c|c|c|c|c|}
\hline Story type & Daily trust & Punch & Total & Percentages \\
\hline News stories & 16 & 21 & 37 & $66 \%$ \\
\hline Feature stories & 3 & 9 & 12 & $21.4 \%$ \\
\hline Editorial & 0 & 0 & 0 & $0 \%$ \\
\hline Opinion articles & 0 & 0 & 0 & $0 \%$ \\
\hline Personal profile & 3 & 3 & 6 & $0 \%$ \\
\hline Cartoon & 0 & 0 & 0 & $1.7 \%$ \\
\hline Pictures & 1 & 0 & 56 & $100 \%$ \\
\hline Total & 23 & 33 & & \\
\hline
\end{tabular}

Source: fieldwork, 2018.

From table 2 above, indicates that Daily trust and the Punch had a total of 37 news stories about women in politics which results to $66 \%$ against other stories which were not about women in politics. Feature stories were 12 in numbers which if calculated is $21.4 \%$ against others that were not about women in politics for the period under investigation, no Nigerian newspaper offer no editorial comment on women in politics. This means there was no editorial written on women in politics. Both newspapers had no opinion articles based women issues. Personality profile accounted for 6 , which is $10.7 \%$ in both newspapers. Cartoon has $0 \%$ which means none of the newspapers show about cartoon relating to women in politics.

Table 3. Coverage of women in the 2015 general elections according to prominence.

\begin{tabular}{|c|c|c|c|c|}
\hline Prominence & Daily trust & Punch & Total & Percentages \\
\hline Front page & 3 & 2 & 5 & $8.9 \%$ \\
\hline Inside page & 19 & 31 & 50 & $89.3 \%$ \\
\hline Back page & 1 & 0 & 1 & $1.8 \%$ \\
\hline Total & 23 & 33 & 56 & $100 \%$ \\
\hline
\end{tabular}

Source: fieldwork, 2018.

From table 3 above, in daily trust and the punch newspapers, out of the 56 total women related stories published, 50 stories which are $89.3 \%$ were placed inside, only 5 stories which are $8.9 \%$ were placed in the front page. And 1 story placed on the back which represents $1.8 \%$.

Table 4. Coverage of Women in 2015 general election according to the quality of report.

\begin{tabular}{|c|c|c|c|c|}
\hline Quality & Daily rules & Punch & Total & Percentages \\
\hline Very high & 1 & 6 & 7 & $12.5 \%$ \\
\hline High & 20 & 27 & 47 & $83.9 \%$ \\
\hline Low & 2 & 0 & 2 & $3.6 \%$ \\
\hline Very low & 0 & 0 & 0 & $0 \%$ \\
\hline Total & 23 & 33 & 56 & $100 \%$ \\
\hline
\end{tabular}

Source: fieldwork, 2018.

From table 4 above, it can be deduced that $12.5 \%$ of the published stories were very high in terms of the quality of reportage or coverage of women in politics. 47, representing $83.9 \%$ were high, 2 stories, representing $3.6 \%$ were low and stories that are very low in terms of quality of reportage.

\section{Discussion of finding}

The presentation and analysis of the data above showed in clear terms the level of coverage the Nigerian newspapers gave to women in 2015 general elections. It is obvious that the Nigerian newspapers did not give women in politics the desires coverage it required as compared to their male counterparts. For the study period of eight months, 422 stories were gathered out of which only 56 were in politics. Therefore, the findings of this study supports the beliefs held by majority of Nigeria's that women in the 2015 general election were not adequately covered when compared to their male counterparts. Also, the study reveals that mass media is pivotal to social change and have the potential to increase the number of women aspirants to political offices. 


\section{Conclusion}

The researcher has been able to demonstrate in this work that Nigerian women still have a long way to go in attaining the pinnacle of political decision making. Giving their poor performance in electoral politics since the country's return to democratic rule, it is apparent that women's struggle to get relevant in political leadership continued of be hindered by certain factors. Patriarchal structure which manifest in 'masculine- model' of politics, lack of internal democracy in parties, the political environment within which women compete, the nature of politics in Nigeria in which is akin to funding of running election campaign and other electoral sundries which most female politicians find excruciating. More so, we wish to reiterate on our earlier argument that, the pursuit of women's development goals, can only be meaningful and attainable when women are positions of authority, which give them power to negotiate and effect policies that are geared toward the goals. The lack of political power continues to constitute a hindrance to women's development.

\section{Recommendations}

1. This study recommends that the Nigerian media should strengthen their coverage of politics especially on women political aspirants by seeing it as part of their civic responsibility.

2. There is need for the print media in Nigeria to create a political platform as part of their newspaper contents whereby women that have performed in leadership roles will be featured so as to serve as motivating factor for their female counterparts.

3. There should be creation of political institutions, development partners and other donor agencies of facilitate women participation in politics and this can be successfully done through the mass media.

4. Women in politics whether during electioneering or not must be on the agenda of the media coverage of national issues.

\section{References}

1. Adedotun (2012). Federal Ministry, Establishment of federal ministry of health.

2. Akinfeleye (1995). Essential newspaper editing and production. Iree: Roalex printing press.

3. Andrew, H.C (2015). How the media control us. New haven: Yale university.

4. Daramola (2012). Introduction to mass communication. Lagos: Rottan Publisher.

5. Dominick, R. \& Wimmier, D. (2011). Mass media research. London: Oxford University.

6. Dovi (2006). Policy maker. Legislative house can determine the extent of women issues.

7. Effah (2002). Statement of problem. Education and a show of cultural and religious barriers.

8. Enebek (2008). Media and freedom of the people. San Francisco: Harpers Collins prints.

9. Hamid A.M. et al. (2014). Understanding magazine production. Kaduna: Deelish printers \& publishers.

10. Hallin, D. C., \& Paolo, M. (2004). Americanization, Globalization and Secularization: Understanding the Convergence of Media Systems and Political Communication. In F. Esser, \& B. Pfetsch (Eds.), Comparing Political Communication: Theories, Cases and Challenges. Cambridge. Cambridge University Press.

11. Lang, K. and Lang, G. (1999). The mass media and voting. In Hanson, J. \& Maxcy, D. Notable selections in mass media. New York: Mc Graw-Hill.

12. Lynn (1978). Political to get Political position.

13. McNair, B. (2002). An Introduction to Political Communication. New York: Routledge.

14. McQuail, I.D. (1987). Mass communication theory (2 ${ }^{\mathrm{ND}}$ ed). London: sage publication.

15. Momodu (2003). The role of the mass media in political mobilization the case of April 12\&19, 2003, general election in Nigeria. Nsukka journal of mass communication. Vol. 11.

16. Nwammu (2012). In different towards politics.

17. Obafemi (2006). Males and femeles in political circles.

18. Obot, C. (2013). Mass Media Electioneering Campaign and Uyo (Nigeria) Voters' Decision During 2011 General Elections. Journal of Politics and Law; 6, no. 1. Retrieved on $15^{\text {th }}$ August, 2016 doi:10.5539/jpl. v6n1p173.

19. Ogbiti \& Onosu (2012). Gender equality. Political circles which negates goal three of MDGs.

20. Ohaja (2003). Population of the study. Trust and punch newspaper.

21. Okeckukwu (1997). Power and authority of court in political entity.

22. Okunoye, N. (2013). Radio and political mobilisation of women in Ado-odo/Ota local government of Ogun State. Global Journal of Applied, Management and Social Sciences.

23. Oso (2012) Mass media are the heart of social and political power: policy process. 
24. Oso, L. Soola, O. Pate, U (2012). Media, Governance and Development in Nigeria: Issues and Trends. Germany: LAP LAM BERT Academic Publishing GmbH \& Co. KG.

25. Pate, U.A. (2011). Media and the Process of Democratization in Nigeria. A paper presented at a Workshop on the Media and Democracy in Nigeria organized by the INEC Press Corps held at Kaduna, December 15-17.

26. Paxton (2007). Media and people. New York: Green wood press.

27. Suleiman, B. (2002). Gender, Media and Democracy: Strategies for Women's Political Empowerment and Participation. National Conference on Democracy and Democratization in Nigeria: An Assessment of the Period 1999- 2001. Organized by The Centre for democratic Research and Training, Mambayya House, Bayero University Kano, (177-201). Kano: Benchmark Publisher.

28. Umechukwu (2004). The role of the mass media in political mobilization. The case of April 12\&19, 2003, general election in Nigeria. Nsukka Journal Of Mass Communication. Vol. 11.

29. Wogu (2003). Role of media in building of the political fabric of a democracy.

30. Zahid, Y. (2012). Private Television Channels as an Agent of Political Awareness in Pakistan, Interdisciplinary Journal Of Contemporary Research In Business, 4(3), 87-106. 